\title{
Growth Potential of the Market Force of Intermediary Structures
}

\author{
Olga Kibik $^{1 *}$, Viacheslav Kotlubay ${ }^{2}$, Iuliia Khaiminova $^{3}$, and Kateryna Belous ${ }^{4}$ \\ ${ }^{1}$ National University “Odessa Law Academy”, Department of National Economy », Ukraine \\ ${ }^{2}$ National University "Odessa Law Academy”, Ukraine \\ ${ }^{3}$ National University "Odessa Law Academy", Ukraine \\ ${ }^{4}$ Odessa National Maritime University, Ukraine
}

\begin{abstract}
The aim of the study is to determine the extent and prospects development of market potential of intermediary structures using an example of waterway transport enterprises. Economic liberalization, development of international economic activity, fragmentation and distantness of suppliers and buyers as preconditions for development of intermediary business structures are determined. The main factors hindering the development of intermediary activities are identified, for instance, imperfect regulatory framework, insufficient intermediary's professionalism, insecurity from intermediaries, low level of responsibility to counterparties, general distrust. Transport companies, in particular, the waterway transport enterprises, are identified as intermediaries that have a significant influence for development of individual economic agents and economic systems. Prospects for the development of sustainable mutually beneficial economic relations or the mutual benefit, the availability of effective information flow, a clear definition of roles, rights and obligations of the involved parties, mutual coordination of behaviour of intermediary structures and clients defined as the main conditions for development of effective interaction of intermediary structures of water transport and clients. In the matter of further studies, attention should be paid to improvement of strengthening mechanism for the responsibility of intermediary structures and clients.
\end{abstract}

\section{Introduction}

Present development conditions of economic activity are characterized by the growing role of intermediaries. Helping to identify and solve problems of economic agents' activity at the market, intermediaries are an important part of the infrastructure of modern markets. Half the turnover of all goods and services is the share of intermediaries in the United Kingdom, the United States, Japan, Germany, and Sweden [1]. In the European Union (EU), according to international statistics for 2009, trade intermediaries accounted for more than $45 \%$ of total number of importers and about $39 \%$ of all exporters. The share of trade intermediaries is about $21 \%$ of the total value of the EU exports and $43 \%$ of the total value of the EU imports. The institution of intermediation has a long history of functioning and numerous contemporary forms are applied in national and global economic systems. Progressive technologies allow intermediation not only in real life. An economic agent commissions intermediary services and expects to improve conditions and results of selling his product. It

*Corresponding author:kibik@ukr.net 
is the basis of increasing competitiveness of goods and, accordingly, competitiveness of the economic agent. However, economic agent has both advantages and risks ordering intermediary services. The possibility of loss of market control, opportunistic behaviour of the intermediary, increasing the agent's dependence on the results of mediation activity, increasing the number of stages of the goods supply, that significantly increase expense of the economic agent, the impossibility of controlling the level of the final price of the goods should be noted as the main risks. Some Japanese distribution channels include more than ten intermediaries. Such number of intermediaries is leads to rise price by $500 \%$ [2].

Transport costs are the integral component of the final cost of goods, besides, transport stipulates the qualitative characteristics of goods. That is, the level of competitiveness of the overwhelming majority of goods is largely determined by the level of transport companies. Transport companies such as waterway transport enterprises are intermediaries. Such intermediaries have important influence on individual economic agents and economic system development.

\section{Analysis of recent researches and publications}

Issues of types and features of intermediaries are studied by A. Zahorodnii, Z. Koval [3], N.N. Kazarian [4], V. Pavlova [5], V. Rieznikova [6]. Study of logistics as a kind of intermediary activity is devoted to works of L. Sosunova, N. Astafieva, O. Yudakova and N. Petrova [7]. Special features of return logistics and connection between points of sale and reverse activity of consumers were solved by F. Milichovskiy [8].

Such researchers as A. Kotlubay, V. Zhykhareva [9], L. Nikolaieva, V. Bereza [10], M. Dooms [11] and others devoted their works to identifying the role of Ukrainian waterway transport intermediary companies in the development of the Ukrainian economic system.

\section{Unsolved aspects of the problem}

However, the studies mentioned above reflect mainly the problem of the development of certain components of the waterway transport specific industries or sectors potential, e.g. shipping companies, ports, cruise companies, inland waterway transport and the like. Issues on development of the Ukrainian waterway transport intermediary companies are extremely relevant and should be investigated in connection with signing of the Free Trade Agreement between Ukraine and the European Union.

The aim of the study is to determine the extent and prospects development of market potential of intermediary structures on an example waterway transport enterprises in modern conditions.

\section{Results}

Ukraine has certain preconditions for the development of intermediary activities, in particular, transport companies which provide intermediary services. Liberalization in the economic sphere, the development of global economic activity, the fragmentation and remoteness of suppliers and buyers should be considered as main factors. The development of legitimate intermediary structures network, in particular in the transport sector, is restricted by such factors as imperfection of the regulatory framework, low level of intermediaries professionalism, the lack of guarantees from intermediaries, low level of responsibility to contractors, general distrust and others. Issues of standardization and licensing of certain types of intermediary activity is still relevant, due to the importance of reducing the risks levels in intermediary activities.

Let us consider the preconditions and prospects for the development of intermediary capacity through the example of maritime enterprises. Through transportation of cargo owned by residents of the country and passengers within the country, transport companies participate in the processes of internal integration. Transport, being a sector of the economic 
system of the country, while providing the international carriage of goods and passengers, is party to integration processes at the international level. All types of transport provide the international carriage of goods. However, the maritime and river transport traditionally takes an important place in such transportation, particularly through the export of transport products. The development of export services, particularly transport services, in modern conditions is a focal area of development of foreign economic activity for all economically developed countries.

The export of transport products can significantly increase foreign exchange earnings to the national budget through the creation and implementation of products with a considerable added value [12].

That is why the development of innovative capacity of the waterway transport is of top priority for Ukraine.

The main conditions for development of effective interaction of structures of waterway transport and clients include the availability of a general strategy of interaction; prospects for the development of sustainable mutually beneficial economic relations or the mutual benefit; strengthening of market positions; provision of balanced and sustainable economic growth; the availability of effective information flow between the intermediary structures and clients; a clear definition of roles, rights and obligations of the parties involved and mutual coordination of behaviour of intermediary structures and clients [13].

Market positions of waterway transport business structures can be strengthened due to increased participation in integration processes. The terms of the Deep and Comprehensive Free Trade Area within the Association Agreement between the European Union and the European Atomic Energy Community and their member states, as one party, and Ukraine as the other party, which entered into force on 1.01.2016, opened the coastal shipping market in the European Union for Ukraine. In conditions of development of the EU coastal shipping market, the said agreement provides Ukraine with the opportunity to enter the closed transport market, which is not yet fully formed. Accordingly, at present Ukraine is a country that has been granted the right for its merchant fleet to sail in the inland waterways of the European Union on a bilateral basis. This creates exceptional opportunities to enter and conquer the segment of the EU inland waterway transport market.

Recently, the annual transportation volume through the EU inland waterways is about 900 million tons of freight. More than two thirds of the above amount is transportation between ports of EU countries at an average distance of $200 \mathrm{~km}$. Own inland fleet deadweight in EU countries is approximately 15 million tons. Price methods of competition and advantages of waterway transport are able to determine the situation, that about $30 \%$ of the cargo volume transported by motor transport on distance over $200 \mathrm{~km}$, can also be refocused to transportation by inland waterway transport. The shortage of carrying capacity is estimated approximately at 4 million tons [14]. In a situation of such shortage, we should expect an increase in the participation of third countries carriers.

This situation creates real opportunities for integration of the Ukrainian waterway transport into the European internal water transport system. To take advantage of the chance, the process of the Ukrainian inland waterway transport reform should be speeded up by adoption of the Law "On Domestic Waterway Transport". Also conditions should be created to restore waterway E-40 that will link the Black and Baltic seas through the Dnieper-Vistula corridor provided for the terms of the European agreement on main inland waterways of international importance, signed on the $19^{\text {th }}$ of January 1996 in Geneva.

To take the unique chance stipulated by the current business trend of the European inland waterway transport market, Ukraine urgently needs to establish the following conditions: formation of legal framework adapted to provisions of international and European laws, establishment of a system of administrative and economic instruments for the national maritime industry development; formation of adequate financial resources for the inland 
waterways system development, elimination of corruption schemes in the sphere of inland waterway navigation regulated by Ukraine, setting the system for promoting the shipbuilding industry development, ensuring of prerequisites for macroeconomic stabilization, which is the basis for growth in the cargo base volume of national transport companies, etc.

Conditions of navigation through the EU inland waterways have specific features and limitations that may in some cases create obstacles for Ukrainian shipping companies. A number of points to Chapter IV of the "Deep and Comprehensive Free Trade Area" of the Association Agreement between the European Union and the European Atomic Energy Community and their member states, of the one part, and Ukraine, of the other part completely exclude the access opportunities for shipping companies established in Ukraine, but not for those in the property of residents of Ukraine or other EU countries. However, the Ukrainian ship-owners whose vessels carry out transportation under flags of other countries will have access to the EU inland waterways.

Comply with the world experience, the most effective instruments of attracting investment and stimulating economic development are tax incentives, loans under favourable terms and subsidies from state budgets of different levels. These instruments are almost not use in Ukraine nowadays. This leads to the fact that the domestic ship owners have to register their vessels under so-called "flags of convenience".

Integration phenomenon in the field of maritime business can be considered also as a component of the overall process of transport and logistics system of Ukraine integration into the European and world economic spaces. Comply with the terms of the Deep and Comprehensive Free Trade Area within the Association Agreement between the European Union and the European Atomic Energy Community and their member states, of the one part, and Ukraine, of the other part, there are requirements on improving the regulatory framework for providing operations of maritime transport. Thus, the limited (3-6 years) period is being introduced for implementation of the EU Directives listed in Annex XXVII-5 Rules Applicable to International Maritime Transport. They concern primarily requirements of safety of navigation and ensuring the social protection of seafarers.

On the other hand, enterprises of maritime transport are active components of the integrated systems of coastal regions, clusters in particular. Creation of transport-logistic and tourist and recreational clusters are most promising directions of integration processes development for coastal regions. It has been proposed to consider the experience of cluster functioning in the European space while developing this form of integration. Successful port and industrial clusters are based on seaports of Rotterdam (Netherlands), London (United Kingdom), Antwerp (Belgium), Marseille-FOS (France), Singapore and others. Port and industrial cluster of Rotterdam combines the capacity of a seaport, petrochemical industry enterprises, shipyards and ship repairing enterprises, agricultural enterprises, insurance, financial and consulting companies, organizations engaged in trade of auto and agricultural industry products. The port industrial cluster of Marseille includes large refineries, petrochemical and metallurgical enterprises, and shipyards.

Based on results of leading scientists studies [10,14, 15], there has been proposed a system of measures, the implementation of which is necessary for the development of potential of Ukraine in the framework of accelerating the integration processes at different levels: regulative framework improvement for the transport system functioning, the implementation of international legal instruments, particularly European Union directives, regulatory framework improvement for the integration activities, clusters operation in particular, creation of favourable legal, organizational and economic conditions aimed to attract investments, including through the establishment of free economic zones aimed to attract foreign investors to the development of transport system elements based on the experience of Asian countries, intensification of participation of Ukraine in the development of the general strategy for the development of international transport corridors network at the 
European and Asian areas within the formation of new transit routes of continental importance, improvement of transit transport infrastructure, development of competitive advantages of domestic waterway transport enterprises, creation of competitive national transit transport operators by main types of TTS, development of logistic support system for transit goods, improvement of pricing system for transport services, formation and development of integrated structures based on transport enterprises, clusters in particular, consideration of environmental impacts when making management decisions in the field of integration transport activities, strengthening of socio-economic responsibility of members of the integrated waterway transport structures, etc.

\section{Conclusions}

Intermediary activity is an important element of the economic system of each country. Creating conditions for the growth of the market power of intermediary business structures is an important task for increasing the competitiveness of economic agents in different levels and fields of activity.

Intermediary companies play an important role in the development of foreign economic activity. Governmental support is appropriate for export-oriented intermediary business structures that contribute to the development of the country export potential. Support may be in the form of preferential taxation, preferential conditions for licenses process (in case of licenses introduction) etc. Transport companies that carry out intermediary services have a special place in the intermediary system.

\section{References}

1. N. Tishkina, Black Sea Economic Studies, 10, 145-149 (2016)

2. O. Dima, Foreign trade: economics, finance, law, 4, 72-82 (2014)

3. A. Zahorodnii, Z.O. Koval, Lviv Polytechnic, 484, 72-79 (2003)

4. N. Kazarian, Herald of GGTU, 2(60), 40-42 (2012)

5. V. Pavlova, V. Hertsyk, Academic review, 2(39), 66-72 (2013)

6 . V. Rieznikova, Theoretical problems of regulating mediation in the economy of Ukraine, Extended abstract of Doctor's thesis (2011)

7. L. Sosunova, N. Astafieva, O. Yudakova and N. Petrova, SHS Web Conf, 62, 07001 (2019)

8. F. Milichovskiy, SHS Web Conf, 61, 01016 (2019)

9. V. Zhyhareva, A. Kotlubay, O. Kibik, Economics of Maritime Transport, Burun Knyga (2012)

10. L. Nikolaieva, V. Bereza, Problems of development of navigational on inland waterways of Ukraine and ways of their solution, Economics, Management, Law: Realities and Perspectives, Paris, 203-207 (2016)

11. M. Dooms, Crafting the integrative value proposition for large scale transport infrastructure hubs: a stakeholder management approach, ASP / VUB Press (2010)

12. N. Garmash, Culture of the People of the Black Sea, 117, 83 - 86 (2007)

13. O. Kibik, O. Podtserkovnyy, V. Kotlubay, \& others, Organizational and Legal Fundamentals of maritime complex of Ukraine, Feniks (2012)

14. A. Kotlubay, Transport Politics of Ukraine and Agreement with the EU, TransportInform.com. http://transportinform.com/corridors/457-transportnaya-politikaukrainy-soglashenie-eu.html (2017)

15. O. Kibik, I. Khaiminova, V. Kotlubay, I. Redina, E. Belous, International Journal of Engineering \& Technology, 7 (4.3), 461-466 (2018) 